\title{
Investigations and preparation of fibrinogen- coated tanned sheep red cells
}

\author{
P. C. DAS
}

From the Regional Transfusion Centre and Blood Products Unit, the Royal Infirmary, Edinburgh

SYNOPSIS The preparation and investigations of tanned sheep red cells coated with human fibrinogen are presented in detail and noted variables are discussed. Both tanning and coating are quick processes. Higher concentrations of tannic acid improved the sensitivity of the cells but required an increased concentration of stabilizing serum to prevent autoagglutination. Fibrinogen concentration above $2 \mu \mathrm{g} / \mathrm{ml}$ had no significant effect, although a concentration above $100 \mu \mathrm{g} / \mathrm{ml}$ sometimes produced cells with incomplete patterns. The $p \mathrm{H}$ of the reaction media may be varied widely, although tanning and coating at a more alkaline $p \mathrm{H}$ yielded cells showing an indistinct pattern. Cells prepared by this method can be stored for at least six months.

The direct agglutination is one of the most sensitive means available for detecting an antibody to particulate antigens. The tanned red cell agglutination test, introduced by Boyden (1951), is a very useful modification for use with soluble antigens. In this method red cells are treated with tannic acid, coated with soluble protein antigens and subsequently used for the detection of a specific antibody. Boyden also demonstrated that his technique could be used for the detection of antigen by haemagglutination inhibition. In this way very small quantities of antigen have been detected (Stavitsky and Ingrahm, 1964).

A large number of workers have reported on the preparation of fresh tanned cells for a variety of antigens, including chorionic gonadotropin, human serum albumin and globulin, egg albumin, ovalbumin, insulin, and diphtheria antigen (Fullthorpe, 1959; Wide, 1962; George and Vaughan, 1962; Shioiri, 1964; Palvonini, 1966; Herbert, 1967a). They found that optima vary for different antigens and results found for one material are not necessarily applicable to others. Furthermore, the main disadvantages of the tanned cell technique are the short time for which the cells can be kept for use after preparation and the great variation in the sensitivity of cells prepared on different occasions.

Detection and quantitation of serum fibrinogen/fibrin degradation products by the haemagglutination inhibition method have been reported from this laboratory (Das, Allan, Woodfield, and Cash, 1967; Mackay, Das, Myerscough, and Cash, 1967; Woodfield, Cole, Allan, and Cash, 1968), for which the production of antigen-coated os cells is an important stage of the assay system. The present paper deals with sensitization of sheep red cells by human fibrinogen and their subsequent storage.

\section{Materials}

FORMALDEHYDE SOLUTION ${ }^{1}$ A $3 \%$ solution $(\mathrm{v} / \mathrm{v})$ was made in normal saline. The $p \mathrm{H}$ was adjusted to $7 \cdot 20-7 \cdot 25$ with $0 \cdot 1$ $\mathrm{N} \mathrm{NaOH}$. 


\section{BUFFERS}

\section{Phosphate buffered saline}

The solution was prepared by adding $35 \mathrm{ml}$ of $\mathrm{Na}_{2} \mathrm{H} \mathrm{PO}_{4}(0 \cdot 15 \mathrm{M})$ and $65 \mathrm{ml}$ of $\mathrm{KH}_{2} \mathrm{PO}_{4}(0 \cdot 15 \mathrm{M})$ to $100 \mathrm{ml}$ of $\mathrm{NaCl}(0 \cdot 15 \mathrm{M})$, and the $p \mathrm{H}$ was adjusted to $6 \cdot 4$. For those experiments in which the effect of variation in $p \mathrm{H}$ was studied, phosphatebuffered saline with different $p \mathrm{H}$ was prepared by adjusting the volumes of $\mathrm{Na}_{2} \mathrm{HPO}_{4}$ and $\mathrm{KH}_{2} \mathrm{PO}_{4}$ accordingly.

\section{Citrate buffer}

This was prepared similarly to phosphate-buffered saline except that $\mathrm{NaCl}$ was replaced by $\mathrm{Na}$ citrate $(0 \cdot 15 \mathrm{M})$. The buffers were stored at $4^{\circ} \mathrm{C}$.

\section{SODIUM AZIDE 1}

This was used as preservative, concentration of $100 \mathrm{mg} / \mathrm{ml}$ being added to the buffers so as to make a final concentration of $1 \mathrm{mg} / \mathrm{ml}$.

\section{Tannic acid ${ }^{2}$}

Fresh stock solutions of tannic acid (Boyden, 1951) were made $(10 \mathrm{mg} / \mathrm{ml}$ in distilled water) for each run, and further dilutions were made in buffers from the stock solution.

\section{SHEEP RED BLOOD CELLS}

These were obtained from the Burroughs Wellcome and Stayne Laboratories, England, and Royal Dick School of Veterinary Studies, Edinburgh. The blood was collected in Alsever's solution, stored as $25 \mathrm{ml}$ aliquots in McCartney bottles at $4^{\circ} \mathrm{C}$ for three to five days before use.

\section{STABILIZING SERUM}

Normal sera from horse, rabbit, and bovine albumin which had a very low titre of natural agglutinin for sheep red cells were used. Residual agglutinins were absorbed by mixing 1 volume of packed normal sheep red cells with 4 volumes of stabilizing sera at $37^{\circ} \mathrm{C}$ for 30 minutes.

\section{ANTIGEN : HUMAN FIBRINOGEN ${ }^{3}$}

This had been prepared by the method of Blömback and Blömback (1956). A freshly prepared $0.02 \%(\mathrm{w} / \mathrm{v})$ solution in distilled water was used as stock preparation. Further dilution was made in the buffer during the coating of the cells. No natural agglutinin against sheep red cells was present in the purified fibrinogen.

Rabbit antihuman fibrinogen serum ${ }^{4}$ was stored ${ }^{1}$ British Drug House Ltd, England

'May \& Baker, England

${ }^{3}$ Kabi Pharmaceuticals Ltd, batch 83164, $97 \%$ clottable

'Behringwerke AG. Germany; batch 606 AC, and $1248 \mathrm{~K}$ at $-20^{\circ} \mathrm{C}$ in small aliquots and a working anti- $\cong$ serum was made on each day by thawing an aliquot and diluting it further as required.

\section{Methods}

FORMALIZATION OF SHEEP RED CELLS This was carried out regularly by the method of $\frac{\vec{\sigma}}{\mathrm{O}}$ Weinbach (1958) as described by Wide (1962), with slight modification. One volume of an $8 \% \mathrm{c}$ (v/v) sheep red cells was mixed with 1 volume of $\overrightarrow{0}$ formaldehyde solution, agitated gently in a glass $\vec{\overrightarrow{ }}$ beaker at $37^{\circ} \mathrm{C}$ by a magnetic stirrer. After 20 to ${ }_{\sigma}^{\omega}$ 24 hours the cells, which had turned a dark brown colour, were washed three times in 50 volumes of $\tilde{N}_{\tilde{O}}^{O}$ distilled water. Finally, a $10 \%(v / v)$ suspension $\omega$ was made in distilled water containing $1 \mathrm{mg} / \mathrm{ml}^{\mathrm{N}}$ $\mathrm{Na}$-azide, and stored at $4{ }^{\circ} \mathrm{C}$. In practice, despite $\overrightarrow{0}$ the excellent capacity for allowing the cells to beo stored for at least six months, for all the present ${ }_{-}$ studies the cells were normally tanned and coated 3 within one to two weeks of formalization.

TANNING OF THE CELLS

The standard method was to take 1 volume of formalinized sheep red cells centrifuged at $1,000 \mathrm{~g}$. for five minutes and washed three times in $50 \stackrel{5}{2}$ volumes of the phosphate-buffered saline. The cells were then mixed with 1 volume of freshly prepared tannic acid solution (in phosphate- 2 buffered saline), incubated in a water bath at $\overline{\overline{0}}$ $56^{\circ} \mathrm{C}$, and stirred at 10 -minute intervals.

\section{COATING OF THE CELLS}

After tanning the cells were washed three times: with 50 volumes of phosphate-buffered saline, and finally suspended in citrate buffer and mixed with an equal volume of purified fibrinogen solu- $₹$ tion (in citrate buffer).

\section{STORAGE OF THE SENSITIZED CELLS} After sensitization of the cells with fibrinogen . the cells were washed four times in $\mathbf{5 0}$ volumes of 0 citrate buffer, suspended as $2.5 \%(\mathrm{v} / \mathrm{v})$ solution in the same buffer containing $0.4 \%$ horse serum aso a stabilizer and $1 \mathrm{mg} / \mathrm{ml} \mathrm{Na-azide} \mathrm{(as} \mathrm{a} \mathrm{dilutingo}$

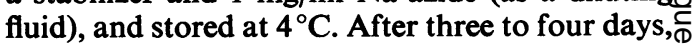
the supernatant above the settled cells was decan- $-?$ ted off and the same volume of fresh diluting 0 fluid added. The concentration of the cells was rechecked, and $2.5 \mathrm{ml}$ aliquots were distributed in plastic vials, left at $4^{\circ} \mathrm{C}$. for the daily tests.

\section{ANTIBODY TITRATION}

Serial dilutions of antifibrinogen serum weres placed in the wells of a microtitre plate' ${ }^{1}$. To ${ }^{1} \mathrm{~V}$ plate, Cook Engineering Co., USA 
volume of antiserum, 1 volume of diluting fluid and 1 volume of $2 \cdot 5 \%$ sensitized cell $(1 \mathrm{vol}$ $\equiv 0.025 \mathrm{ml}$ ) was added. Controls, including 2 volumes of diluting fluid and 1 volume of sensitized cells, were incorporated in each plate. The plates were shaken and placed at $4^{\circ} \mathrm{C}$ overnight. A smooth mat of cells at the bottom of the wells was designated as positive $(+)$ and a 'button' of cells in the centre of the wells was called negative $(-)$; intermediate reactions were recorded as \pm .

The end point of the antibody titre was taken to be the highest dilution of antiserum causing complete agglutination of the cells, and the titre of the antiserum was expressed as the reciprocal of the initial dilution of the antiserum. The results of different experiments are not strictly comparable unless specifically stated as several different batches of antiserum of different titres were used.

\section{Results}

Haemolysis and spontaneous agglutination occurred at the formalization stage only once in $\mathbf{8 0}$ batches of cells.

Three batches of cells were formalinized and stored at $4^{\circ} \mathrm{C}$ for various lengths of time, ranging from one week to six months, and portions of them were simultaneously tanned and coated by

\begin{tabular}{llcl}
\hline Age of Cells & \multicolumn{3}{l}{ Titre Against Antifibrinogen Serum } \\
\cline { 2 - 4 } & \multicolumn{3}{l}{ Cell Batch } \\
\cline { 2 - 4 } & Number $P_{2} D$ & Number $P_{5} D$ & Number $P_{3} D$ \\
\hline One week & 64,000 & 96,000 & 32,000 \\
One month & 48,000 & 128,000 & 48,000 \\
Two months & 96,000 & 64,000 & 48,000 \\
Four months & 64,000 & 96,000 & 48,000 \\
Six months & 64,000 & 64,000 & 48,000 \\
\hline
\end{tabular}

Table I Titre of antifibrinogen serum given by three batches of formalinized cells, stored at $4^{\circ} \mathrm{C}$, tanned and coated after different periods of time

the standard method. Results of the titration of $\bar{\omega}$ an antiserum are presented in Table $I$, and show that the age of the cells had no significant influence on the results obtained.

The results of the investigation of different variables at the tanning stage are summarized in $\overrightarrow{\overrightarrow{0}}$ Table II.

\section{TANNIC ACID CONCENTRATION}

When other variables were kept constant, an $\frac{\rho}{\partial}$ increased amount of tannic acid gave a somewhat $\vec{\bullet}$ greater final sensitivity. However, slight autoagglutination appeared in the controls at the higher tannic acid concentration (Table II). This could be due to an inadequate concentration of stabilizing agent in the final assay.

\begin{tabular}{|c|c|c|c|c|c|c|}
\hline $\begin{array}{l}\text { Tannic Acid } \\
\text { Concentration (1) }\end{array}$ & $\mathrm{p} H$ & $\begin{array}{l}\text { Temperature } \\
\text { (in Centigrade) }\end{array}$ & $\begin{array}{l}\text { Time (in } \\
\text { Minutes) }\end{array}$ & $\begin{array}{l}\text { Cell Percentage }(v / v) \text { in } \\
\text { Phosphate-buffered Saline }\end{array}$ & $\begin{array}{l}\text { Titre of } \\
\text { Antiserum }\end{array}$ & Control $^{1}$ \\
\hline \multicolumn{7}{|c|}{ Effects of tannic acid } \\
\hline 5,000 & $6 \cdot 4$ & 56 & 60 & 2 & 128,000 & \pm \\
\hline 10,000 & $6 \cdot 4$ & 56 & 60 & 2 & 96,000 & \pm \\
\hline 20,000 & $6 \cdot 4$ & 56 & 60 & 2 & 64,000 & - \\
\hline 40,000 & $6 \cdot 4$ & 56 & 60 & 2 & 64,000 & - \\
\hline 80,000 & $6 \cdot 4$ & 56 & 60 & 2 & 48,000 & - \\
\hline 160,000 & $6 \cdot 4$ & 56 & 60 & 2 & 32,000 & - \\
\hline 320,000 & $6 \cdot 4$ & 56 & 60 & 2 & 32,000 & - \\
\hline \multicolumn{7}{|l|}{ Effects of $\mathrm{pH}$} \\
\hline 40,000 & $5 \cdot 0$ & 56 & 60 & 2 & 16,000 & - \\
\hline 40,000 & $6 \cdot 0$ & 56 & 60 & 2 & 64,000 & - \\
\hline 40,000 & $6 \cdot 4$ & 56 & 60 & 2 & 64,000 & - \\
\hline 40,000 & $7 \cdot 2$ & 56 & 60 & 2 & 64,000 & - \\
\hline 40,000 & $7 \cdot 6$ & 56 & 60 & 2 & 96,000 & \pm \\
\hline 40,000 & $8 \cdot 0$ & 56 & 60 & 2 & 96,000 & \pm \\
\hline \multicolumn{7}{|c|}{ Effects of temperature } \\
\hline 40,000 & $6 \cdot 4$ & 22 & 60 & 2 & 32,000 & - \\
\hline 40,000 & 6.4 & 37 & 60 & 2 & 64,000 & - \\
\hline 40,000 & $6 \cdot 4$ & 56 & 60 & 2 & 64,000 & - \\
\hline \multicolumn{7}{|c|}{ Effects of time of incubation } \\
\hline 40,000 & 6.4 & 56 & 15 & 2 & 64,000 & - \\
\hline 40,000 & 6.4 & 56 & 30 & 2 & 64,000 & - \\
\hline 40,000 & 6.4 & 56 & 60 & 2 & 64,000 & - \\
\hline 40,000 & $6 \cdot 4$ & 56 & 120 & 2 & 64,000 & - \\
\hline \multicolumn{7}{|c|}{ Effects of cell concentration } \\
\hline 40,000 & $6 \cdot 4$ & 56 & 60 & 2 & 64,000 & - \\
\hline 40,000 & $6 \cdot 4$ & 56 & 60 & 4 & 32,000 & - \\
\hline 40,000 & 6.4 & 56 & 60 & 8 & 16,000 & - \\
\hline
\end{tabular}




\section{EFFECT OF $p \mathrm{H}$}

The results indicated that though a higher sensitivity was obtained at a more alkaline $p \mathrm{H}$, the cells provided less distinct patterns (Table II); at an acid $p \mathrm{H}$ sensitivity was significantly impaired. A $p \mathrm{H}$ of either 6.4 or $7 \cdot 2$ was found to be equally satisfactory.

\section{TEM PER A T URE}

Tanning was carried out at $22^{\circ} \mathrm{C}, 37^{\circ} \mathrm{C}$ or $56^{\circ} \mathrm{C}$. It was found that both $37^{\circ} \mathrm{C}$ and $56^{\circ} \mathrm{C}$ were equally effective. A slightly lower titre was obtained at room temperature. Tanning at $56^{\circ} \mathrm{C}$ was therefore adopted in an attempt to adhere to Wide's (1962) basic method.

\section{TIME OF INCUBATION}

Tanning was carried out at $56^{\circ} \mathrm{C}$ for $15,30,60$, and 120 minutes, and the results show that the process appears to be rapid (Table II); increasing incubation time has no effect on the sensitivity of the cells processed. An incubation time of 60 minutes was arbitrarily adopted for the routine tanning procedure described in this study.

\section{CELL CONCENTRATION}

This experiment was designed to investigate the proportion of cells necessary for optimal tanning and subsequent coating by human fibrinogen.
Formalinized cells were washed and suspensions of $2 \%, 4 \%$, and $8 \%,(\mathrm{v} / \mathrm{v})$ were made. They wer $\overline{\overline{6}}$ then tanned and coated by the standard methog using the same quantities of reagents. Result (Table II) show that an increase in the quantit of cells caused a drop in titre: a $2 \%(\mathrm{v} / \mathrm{v})$ susper sion of cells was therefore adopted for the routine procedure.

EFFECT OF PHOSPHATE-BUFFERED SALINE AND CITRATE BUFFER

Five batches of cells were simultaneously coated in either of the two buffers. With no batch dif titration against an antifibrinogen serum shog, any significant variation of titres between thos coated using either buffer. In practice citrate buffer, $p H 6.4$, was routinely used as the diluting agent to prevent clot formation which mighe have occurred if phosphate-buffered saline has been used with plasma or fibrinogen.

\section{EFFECT OF USING DIFFERENT CONCEN-} TRATIONS OF ANTIGEN

Seven batches of cells were simultaneously tanneg and then sensitized with a solution of fibrinoged containing between 0.1 and $100 \mu \mathrm{g} / \mathrm{ml}$. It wàs evident that a fibrinogen concentration in excess of $2 \mu \mathrm{g} / \mathrm{ml}$ did not improve the sensitivity (Tab) III). Furthermore, occasionally an incomple $\bar{g}$ pattern emerged in the control when the fibrinoge

\begin{tabular}{lllllll}
\hline $\begin{array}{l}\text { Fibrinogen } \\
\begin{array}{l}\text { Concentration } \\
(\mu \mathrm{g} / \mathrm{ml})\end{array}\end{array}$ & $\mathrm{pH}$ & $\begin{array}{l}\text { Temperature } \\
\text { (in Centigrade) }\end{array}$ & $\begin{array}{l}\text { Time of } \\
\text { Incubation } \\
\text { (in Minutes) }\end{array}$ & $\begin{array}{l}\text { Cell Percentage } \\
(v / v) \text { in Citrate } \\
\text { Buffer }\end{array}$ & $\begin{array}{l}\text { Number of } \\
\text { Cell Batch }\end{array}$ & $\begin{array}{l}\text { Titre of } \\
\text { Antiserum }\end{array}$
\end{tabular}

Effects of fibrinogen concentration

$\begin{array}{rrr}0.1 & 6.4 & 37 \\ 0.5 & 6.4 & 37 \\ 1.0 & 6.4 & 37 \\ 2.0 & 6.4 & 37 \\ 10.0 & 6.4 & 37 \\ 50.0 & 6.4 & 37 \\ 100.0 & 6.4 & 37\end{array}$

$\begin{array}{ll}60 & 4 \\ 60 & 4 \\ 63 & 4 \\ 69 & 4 \\ 60 & 4 \\ 60 & 4 \\ 60 & 4\end{array}$

\section{Effects of $\mathrm{pH}$}

$\begin{array}{cc}2 \cdot 0 & 5 \cdot 0 \\ 2 \cdot 0 & 6 \cdot 0 \\ 2 \cdot 0 & 6 \cdot 4 \\ 2 \cdot 0 & 7 \cdot 2 \\ 2 \cdot 0 & 7 \cdot 6 \\ 2 \cdot 0 & 8 \cdot 0\end{array}$

$\begin{array}{ll}\mathbf{5} \cdot 0 & 37 \\ \mathbf{6} \cdot \mathbf{0} & 37 \\ \mathbf{6 \cdot 4} & 37 \\ \mathbf{7 \cdot 2} & 37 \\ \mathbf{7 \cdot 6} & 37 \\ \mathbf{8 \cdot 0} & 37\end{array}$

Effects of time of incubation

$\begin{array}{lll}2 \cdot 0 & 6 \cdot 4 & 37 \\ 2 \cdot 0 & 6 \cdot 4 & 37 \\ 2 \cdot 0 & 6 \cdot 4 & 37 \\ 2 \cdot 0 & 6 \cdot 4 & 37 \\ 2 \cdot 0 & 6 \cdot 4 & 37\end{array}$

\begin{tabular}{l}
37 \\
37 \\
37 \\
37 \\
37 \\
37 \\
\hline \\
\\
37 \\
37 \\
37 \\
37 \\
37
\end{tabular}

Effects of temperature

$\begin{array}{ccc}\text { Effects of temperature } & \\ 2 \cdot 0 & 6.4 & 22 \\ 2.0 & 6.4 & 22 \\ 2.0 & 6.4 & 37 \\ 2.0 & 6.4 & 37 \\ & & \\ \text { Effects of cell concentration } & \\ 2.0 & 6.4 & 37 \\ 2.0 & 6.4 & 37 \\ 2.0 & 6.4 & 37\end{array}$

Table III Investigations at the coating stage 
concentration was in the region of $100 \mu \mathrm{g} / \mathrm{ml}$. There was also evidence that the sensitivity was considerably diminished if the fibrinogen concentration was below $2 \mu \mathrm{g} / \mathrm{ml}$.

\section{EFFECT OF VARYING THE $p H$}

Six batches of cells were uniformly treated with tannic acid $(1: 40,000)$, and then suspended in phosphate-buffered saline of varying $p \mathrm{H}$ values between 5 and 8 , and coated identically using fibrinogen solution in an appropriate buffer. When tested against an antifibrinogen serum it was found that there was no difference in sensi-

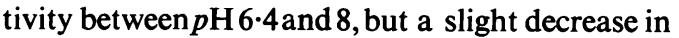
titre was noticed at low $p \mathrm{H}$, and occasionally an incomplete pattern appeared in the control in the more alkaline solutions (Table III).

\section{EFFECT OF VARYING THE INCUBATION TIME AND TEMPERATURE}

Five batches of cells were tanned and coated by the standard method, except that the time during which each batch was left in $37^{\circ} \mathrm{C}$ water bath varied from 15 to 180 minutes. In a second set of experiments two batches of cells were sensitized for 60 minutes at $37^{\circ} \mathrm{C}$ and $22^{\circ} \mathrm{C}$. Results are shown in Table III, and indicate that the cells were well sensitized by exposure to fibrinogen for 15 minutes; any longer periods of coating did not increase their reactivity. Furthermore, there was no consistent difference between the batches of cells sensitized at $37^{\circ} \mathrm{C}$ and at room temperature.

\section{EFFECT OF CONCENTRATION OF CELLS} Cells were tanned in bulk, being treated with an equal volume of $1: 40,000$ tannic acid, and after washings and resuspension, these tanned cells were distributed as $2 \%, 4 \%$, and $8 \%(\mathrm{v} / \mathrm{v})$ suspension in three different containers. The cells in each container were then coated with fibrinogen by the standard technique, and finally a $2.5 \%(\mathrm{v} / \mathrm{v})$ suspension was made in diluting fluid.

Table III shows that this resulted in a variation of the titre when these cells were tested with an antifibrinogen serum, so that larger quantities of cells produced a somewhat lower titre. A $2 \%$ cell suspension was therefore adopted for coating purposes.

\section{STABILIZATION STAGE}

During the present study experiments were performed on different stabilizers. Using 1:40,000 tannic acid as the standard tanning technique, fibrinogen-coated cells were found to be effectively stabilized by $0.4 \%$ horse serum, $0.2 \%$ normal rabbit serum and $0.1 \%$ bovine albumin, or it was also demonstrated that previously observed autoagglutination of cells when tanned with 1:5,000 tannic acid (Table II) could be pre vented by increasing the concentration of stabilizing horse serum to $1 \%$.

\section{STORAGE OF SENSITIZED CELLS}

Control tests upon batches of fibrinogen-coated cells were carried out on the same day as they had been prepared and again three days after pre paration. Before the second control test the supernatant above the settled cells was removed? and the same amount of diluting fluid added, and $\vec{b}$ stored at $4^{\circ} \mathrm{C}$. Table IV shows the results of such experiments. The titre was usually found highef్ in the second control test than in the first one After the change of supernatant the fibrinogen coated cells retained, for four to five months, anw almost unchanged capacity to react in the test (Table V).

\begin{tabular}{|c|c|c|}
\hline \multirow[b]{2}{*}{$\begin{array}{l}\text { Cell Batch } \\
\text { Number }\end{array}$} & \multicolumn{2}{|l|}{ Titre } \\
\hline & $\begin{array}{l}\text { First Control } \\
\text { Experiment }\end{array}$ & $\begin{array}{l}\text { Second Control } \\
\text { Experiment }\end{array}$ \\
\hline F20 & 64,000 & 96,000 \\
\hline F3 & 48,000 & 96,000 \\
\hline F4 & 64,000 & 128,000 \\
\hline F5 & 192,000 & 192,000 \\
\hline P2 & 32,000 & 64,000 \\
\hline M1 & 96,000 & 96,000 \\
\hline Ex 4 & 32,000 & 64,000 \\
\hline Ex 3 & 96,000 & 128,000 \\
\hline
\end{tabular}

Table IV Titre of an antifibrinogen serum against eight batches of cells ${ }^{1}$

'The first control experiments were performed on the same day the cells were sensitized. The second control experiments were performed three days later.

\begin{tabular}{|c|c|c|c|}
\hline \multirow[b]{2}{*}{$\begin{array}{l}\text { Time of Storage } \\
\text { (in Months) }\end{array}$} & \multicolumn{3}{|l|}{ Titre } \\
\hline & $\begin{array}{l}\text { Cell Batch } \\
\text { Number } M S_{1}\end{array}$ & $\begin{array}{l}\text { Cell Batch } \\
\text { Number } E_{1}\end{array}$ & $\begin{array}{l}\text { Cell Batch } \\
\text { Number } P_{1}\end{array}$ \\
\hline $\begin{array}{l}1 \\
2 \\
3 \\
4 \\
5\end{array}$ & $\begin{array}{r}96,000 \\
128,000 \\
96,000 \\
96,000 \\
64,00\end{array}$ & $\begin{array}{c}67,000 \\
64,000 \\
64,000 \\
67,000 \\
-\end{array}$ & $\begin{array}{c}96,000 \\
64,000 \\
96,000 \\
96,000 \\
-\end{array}$ \\
\hline
\end{tabular}

Table V Titre of an antifibrinogen serum against three batches of sensitized cells stored at $4^{\circ} \mathrm{C}$ for varying $\mathrm{N}$ periods of time

\section{Discussion}

The present investigations suggests that formalin- $-\frac{0}{\Phi}$ ized and coated cells can be stored for at least $\stackrel{\circ}{\circ}$ five to six months, thus minimizing the technical $\stackrel{\odot}{\varnothing}$ disadvantages of the short storage time aftero preparation, and the great variation in separately prepared batches of cells (Read and Stone, 1958;응 Herbert, 1967b). The quantity of tannic acid, which is a hydrogen donor on biological membrane and interacts in solution with quaternar 
nitrogen compounds (Allison, 1968; Nash, 1966) and thereby alters the stability of cell membranes, was of the first importance; the more tannic acid used the greater was the sensitivity. However, greater concentration of tannic acid $(1: 5,000)$ requires higher concentration of stabilizing serum $(1 \%)$ to effect adequate stabilization and thus avoid the appearance of autoagglutinable cells (Herbert, 1967a). In the routine method, $1: 40,000$ tannic acid is used though lower concentrations have sometimes been found to be effective in other systems (Boyden and Sorkin, 1955; Heller, Jacobson, Kolodny, and Kammerer, 1954). On the other hand Fox, Wide, Killander, and Gemzell (1965) used 1:20,000 tannic acid for fibrinogen-coated cells. Some batches of cells may be abnormally sensitive or resistant to the action of tannic acid and it may therefore be worthwhile to carry out preliminary investigations with several different concentrations of tannic acid.

Tanning appears to be a rapid process and could be effectively done at $37^{\circ} \mathrm{C}$ and $56^{\circ} \mathrm{C}$, which is in agreement with other workers (Boyden, 1951; Stavitsky, 1954; George and Vaughan, 1962; Heller et al, 1954; Wide, 1962; Herbert, 1967a). A slightly lower titre was obtained when the cells were tanned at room temperature $\left(22^{\circ} \mathrm{C}\right)$ which was also claimed to be effective by Boyden and Sorkin (1955) during the tanning procedure.

The cells were found to be adequately coated by fibrinogen solution containing 2-100 $\mu \mathrm{g} / \mathrm{ml}$. This is similar to the findings of other authors (Linz, Lecocq, and Mandelbaum, 1961; Linz and Lecocq, 1962; Merskey, Kleiner, and Johnson, 1966; Herbert, 1967a) and is considered to be due to adsorption on the cells of only a very small part of the total protein present. However, some workers have reported optimum concentrations of antigen for sensitization of the cells (Boyden, 1951; Wide, 1962; Steffen and Rosak, 1963). Furthermore, George and Vaughan (1962) found a direct relationship between the quantity of antigen used to coat the cell and the titres obtained. Herbert (1967a), however, has found a relationship of this type only when fresh cells are employed but not with formalinized cells. Slight autoagglutination, noticed at fibrinogen concentrations in excess of $100 \mu \mathrm{g} / \mathrm{ml}$, is similar to the findings of Ferreira, Silva, Murat, and Ferraz (1964) who reported that excess of fibrinogen produced large clumps of cells making them unsuitable for test purposes.

The length of time required to sensitize the cells was found to be short. The $p \mathrm{H}$ at which this can be done may be varied widely, though tanning and coating at more alkaline $p \mathrm{H}$ yielded cells showing an incomplete pattern and occasional moderate autoagglutination (Wide, 1962). This may be due to denaturation and precipitation of surface protein of the cells or of fibrinogen at alkaline $p \mathrm{H}$. Lower titres, obtained when the

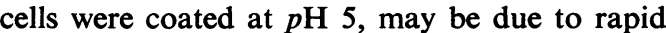
digestion of fibrinogen at acid $p \mathrm{H}$ (Watt, 1968).
Cells sensitized by the standard technique gave excellent results. One of the reasons is perhaps that highly purified fibrinogen was used instead of plasma, since it is known that there are distinc $\bar{E}$ advantages in using purified materials (Fisher 1952; Linz and Lecocq, 1962; George and Vaughan, 1962). However, small batches of cellso produced variable titres $(1: 16,000$ to $1: 256,000)$ 음 This is possibly due to the antigen being denatured to a different extent on different occasion $\overline{\$}$ (Christian, 1958; George and Vaughan, 1962 Maurer, Gerulat, and Pinchuck, 1963; Epstein and Gross, 1964) and/or some batches of cells are abnormally reactive to tannic acid (Herbert $\overrightarrow{\vec{w}}$ 1967a).

The cells stored at $4{ }^{\circ} \mathrm{C}$ after the change op supernatant usually showed higher titres than thei first control run. This is probably due to loss of antigen into the liquid as shown by Wide (1962): Although no free fibrinogen could be detected inco the supernatant by haemagglutination inhibition, this does not preclude the possibility that theantigen present was too small to be detected? Lately we have been able to store the sensitizeक cells for nine to 10 months without any apparent? loss of reaction.

The sensitized cells were successfully used ino haemagglutination inhibition reaction for theo detection of serum fibrinogen/fibrin degradations products (Das et al, 1967). The production of highly sensitive cells has distinct advantages, for the cells can be stored for longer periods and 8 in haemagglutination inhibition reaction, more dilute antiserum can be used, which not only⿳⺈ allows for economy but also improves the sen-? sitivity of the test system (Das, 1968).

The author would like to thank Drs R. A Cumming, J. D. Cash, and the staff of the Blood Transfusion Service, Edinburgh, for excellent laboratory facilities, sustained encouragemento and help; Dr W. J. Herbert, Department of Immunology, University of Glasgow, for hiso active interest and kindly advice. This research programme is supported by the Scottish Nationalo Blood Transfusion Association and the ScottishN Hospitals Endowment Research Trust.

\section{References}

Allison, A. C. (1968). Some effects of pharmacologically active compounds on membranes. Brit. med. Bull. 24, 135-140. Blomback, B., and Blomback, M. (1956). Purification of human음 and bovine fibrinogen. Ark. kemi., 10, 415-443.

Boyden, S. V. (1951). The adsorption of proteins on erythrocytes $\Omega$ treated with tannic acid and subsequent haemagglutination by antiprotein sera. J. exp. Med., 93, 107-120.

Boyden, S. V., and Sorkin, E. (1955). A study of antigens active in the tannic acid haemagglutination test present in filtrates of culture of mycobacterium tuberculosis. J.O Immunol., 75, 15-21.

Christian, C. L. (1958). Characterization of the 'reactant' (gamma globulin factor) in the F II precipitin reaction and the F If으 tanned sheep cell agglutination test. J.exp. Med, 108, 139-? 157. 
Das, P. C., Allan, A. G. E., Woodfield, D. G., and Cash, J. D. (1967). Fibrin degradation products in sera of normal subjects. Brit. med. J., 4, 718-720.

Das, P. C. (1968). PhD Thesis, University of Edinburgh. Studies of the fibrinolytic enzyme system with special reference to circulating fibrin/fibrinogen degradation products and to coagulation factor XIII.

Epstein, W. V., and Gross, D. (1964). Naturally occurring human antibody reacting with Bence Jones proteins. J. exp. Med., 120, 733-745.

Ferreira, H. C., Silva, M. P., Murat, L. G., and Ferraz, C. N. (1964). Fibrinogen-poor platelets as one of the defects in Glanzmann purpura. Rev. Hosp. Clin. Fac. Med. S. Paulo, 19, 293-300.

Fisher, S. (1952). The estimation in vitro of small amounts of diphtheria antitoxin by means of a haemagglutination technique. J. Hyg. (Lond.), 50, 445-456.

Fox, F. J. Jr, Wide, L., Kellander, J., and Gemzell, C. (1965). Determination of fibrinogen and fibrinolysis products in human plasma by an immunochemical method. Scand. J. clin. Lab. Invest., 17, 341-348.

Fulthorpe, A. J. (1959). Factors influencing haemagglutination tests with tetanus anti-toxin. Immunology, 2, 104-111.

George, M., and Vaughan, J. H. (1962). Observations on the nature of the antigen in tanned red cell haemagglutination. J. Immunol., 88, 191-198.

Herbert, W. J. (1967a). A study of factors influencing the sensitivity to antibody of tanned, ovalbumin-coated, formalinized sheep red cells. Immunology, 13, 459-468.

Herbert, W. J. (1967b). In Hand Book of Experimental Immunology, pp. 720-744, edited by D. M. Weir, Blackwell, Oxford.

Heller, G., Jacobson, A. S., Kolodny, M. H., and Kammerer, W. H. (1954). The hemagglutination test for rheumatoid arthritis. II. The influence of human plasma fraction II (gamma globulin) on the reaction. J. Immunol., 72, 66-78.

Linz, R., Lecocq, E., and Mandelbaum, E. (1961). The adsorption of antigens on tanned erythrocytes. Ann. Inst. Pasteur, 101, 367-381.

Linz, R., Lecocq, E. (1962). Agglutination of tanned erythrocytes treated by two antigens. I. Erythrocytes treated by a mixture of two antigens. Ann. Inst. Pasteur, 102, 92-107.
Mackay, A. V. P., Das, P. C., Myersccugh, P. R., and Cash, J. D. (1967). Fibrinolytic components of human uterine arterial and venous blood. J. clin. Path., 20, 227-230.

Maurer,P. H., Gerulat, B. F., and Pinchuck, P. (1963). Antigenicity of polypeptides. V. Studies in rabbits. J. Immunol., 90, 381-387.

Merskey, C., Kleiner, G. J., and Johnson, A. J. (1966). Quantita- 음 tive estimation of split products of fibrinogen in human serum, relation to diagnosis and treatment. Blood, 28, 1-18.

Nash, T. (1966). In Low Temperature Research in Biology, p. 179, edited by $\mathbf{H}$. T. Merryman and E. C. Bate-Smith. Academic Press, New York and London.

Palvonini, F. (1966). In Immunological Properties of Protein Hormones, p.67. Academic Press, New York and London. $\overparen{D}$

Read, C. H., and Stone, D. B. (1958). An immunologic assay for $\varrho$ minute amounts of human pituitary growth hormone. $\frac{\Omega}{\mathcal{N}}$ Amer. J. Dis. Childh., 96, 538.

Shioiri, K. (1964). The observation of proteins adsorbed on $\overrightarrow{0}$ erythrocytes treated with tannic acid in passive hemagglutination tests (Boyden's method). Jap. J. exp. Med., 34, $\overrightarrow{\vec{\omega}}$ 345-359.

Stavitsky, A. B. (1954). Micro methods for study of proteins and $\underset{\overbrace{}}{\Omega}$ antibodies. I. Procedure and general applications of hemagglutination and hemagglutination-inhibition reactions with tannic acid and protein-treated red blood cells.J. Immunol., $\omega$ 72, 360-367.

Stavitsky, A. B. and Ingrahm, J. S. (1964). In Immunological ? Methods, edited by J. F. Ackroyd, Blackwell, Oxford.

Steffen, C., and Rosak, M. (1963). In vitro demonstration of anti- 6 ovalbumin specificity of lymph node cells in delayed type 음 hypersensitivity. J. Immunol., 90, 337-346.

Watt, J. G. (1958). Personal communication.

Weinbach, R. (1958). Die Verwendbarkeit formolbehandelter $\$ Erythrocyten als Antigen-tröger in der indirekten Haemag. glutination. Schweiz. Z. Path., 21, 1043-1052.

Wide, L. (1962). An immunological method for the assay of human chorionic gonadotrophin. Acta. endocr $(K b h), 41$, suppl. 70.

Woodfield, D. G., Cole, S. K., Allan, A. G. E., and Cash, J. D. ㄱ (1968). Serum fibrin degradation products throughout normal pregnancy. Brit. med. J., 4, 665-668. 